\title{
Hot-Dip Aluminizing of Low Carbon Steel Using Al-7Si-2Cu Alloy Baths
}

\author{
Prashanth Huilgol, ${ }^{1}$ Suma Bhat, ${ }^{2}$ and K. Udaya Bhat ${ }^{1}$ \\ ${ }^{1}$ Department of Metallurgical and Materials Engineering, National Institute of Technology Karnataka, Surathkal, \\ Mangalore 575025, India \\ ${ }^{2}$ Department of Mechanical Engineering, Srinivasa School of Engineering, Mukka, Surathkal, Mangalore 575021, India
}

Correspondence should be addressed to K. Udaya Bhat; udayabhatk@gmail.com

Received 17 May 2013; Accepted 14 August 2013

Academic Editor: Masahiro Fukumoto

Copyright (C) 2013 Prashanth Huilgol et al. This is an open access article distributed under the Creative Commons Attribution License, which permits unrestricted use, distribution, and reproduction in any medium, provided the original work is properly cited.

\begin{abstract}
Hot-dip aluminizing of low carbon steel was done in molten $\mathrm{Al}-7 \mathrm{Si}-2 \mathrm{Cu}$ bath at $690^{\circ} \mathrm{C}$ for dipping time ranging from 300 to 2400 seconds. Characterization of the intermetallics layer was done by using scanning electron microscope with energy dispersive spectroscopy. Four intermetallic phases, $\tau_{5}-\mathrm{Al}_{7} \mathrm{Fe}_{2} \mathrm{Si}, \theta-\mathrm{FeAl}_{3}, \eta-\mathrm{Fe}_{2} \mathrm{Al}_{5}$, and $\tau_{1}-\mathrm{Al}_{2} \mathrm{Fe}_{3} \mathrm{Si}_{3}$, were identified in the reaction layer. $\tau_{5}$ $\mathrm{Al}_{7} \mathrm{Fe}_{2} \mathrm{Si}$ phase was observed adjacent to aluminum-silicon topcoat, $\theta-\mathrm{FeAl}_{3}$ between $\tau_{5}$ and $\eta-\mathrm{Fe}_{2} \mathrm{Al}_{5}, \eta$ - $\mathrm{Fe}_{2} \mathrm{Al}_{5}$ adjacent to base material, and $\tau_{1}-\mathrm{Al}_{2} \mathrm{Fe}_{3} \mathrm{Si}_{3}$ precipitates within $\mathrm{Fe}_{2} \mathrm{Al}_{5}$ layer. The average thickness of $\mathrm{Fe}_{2} \mathrm{Al}_{5}$ layer increased linearly with square root of dipping time, while for the rest of the layers such relationship was not observed. The tongue-like morphology of $\mathrm{Fe}_{2} \mathrm{Al}_{5}$ layer was more pronounced at higher dipping time. Overall intermetallic layer thickness was following parabolic relationship with dipping time.
\end{abstract}

\section{Introduction}

Hot-dip aluminizing is an effective and inexpensive coating process to protect steels from oxidation $[1,2]$. The quality of coating depends on the properties of the intermetallics layer forming at the interface. A brittle intermetallic layer may peel off from surface during forming operations [3], which generally follows aluminizing treatment. Therefore it becomes necessary to study the formation of intermetallics layer under different conditions. Gebhardt and Obrowski [4] observed that when steel comes in contact with the molten aluminum, the major intermetallic layer formed is $\mathrm{Fe}_{2} \mathrm{Al}_{5}$. Bouché et al. [5] reported the formation of two intermetallic layers, namely, $\mathrm{Fe}_{2} \mathrm{Al}_{5}$ and $\mathrm{FeAl}_{3}$, when solid iron is dipped in liquid aluminum over the temperature range $700^{\circ} \mathrm{C}$ to $900^{\circ} \mathrm{C}$. They reported that the growth behaviour is initially nonparabolic which is followed by parabolic. Kinetic studies done by Bouayad et al. [6] for medium dipping times ( $<45 \mathrm{~min}$ ) showed that the growth of $\mathrm{Fe}_{2} \mathrm{Al}_{5}$ layer is diffusion controlled and $\mathrm{FeAl}_{3}$ layer growth is linear with time.
Many researchers tried to explain the observed tongue-like morphology of the intermetallic layers [5-7] and are of the opinion that the anisotropic diffusion is responsible for this growth. Springer et al. [8] investigated interdiffusion between low carbon steel and pure $\mathrm{Al}(99.99 \%)$ and $\mathrm{Al}$ alloy $(\mathrm{Al}-5 \% \mathrm{Si})$ between temperatures $600^{\circ} \mathrm{C}$ and $675^{\circ} \mathrm{C}$ and showed that growth rate of $\eta$-layer $\left(\mathrm{Fe}_{2} \mathrm{Al}_{5}\right)$ is diffusion controlled and it governs overall intermetallic layer growth. Cheng and Wang [9] observed that as the silicon content in the molten bath increases, the thickness of intermetallic layer decreases as well as the interface between intermetallic layer and steel substrate becomes flat. Cheng and Wang [10] investigated the effect of nickel preplating on the formation of intermetallic layer when the mild steel is dipped in pure Al. Li et al. [11] investigated the phase constituents within the intermetallic layer formed during hot-dip aluminizing. Bhat et al. [12] discussed the effect of $\mathrm{ZnCl}_{2}+\mathrm{NH}_{4} \mathrm{Cl}$ flux on the microstructural formation during dip aluminizing of steel with aluminum.

It is also reported that $\mathrm{Si}$ and $\mathrm{Cu}$ are the alloying elements in the aluminizing bath which are effective in restraining 


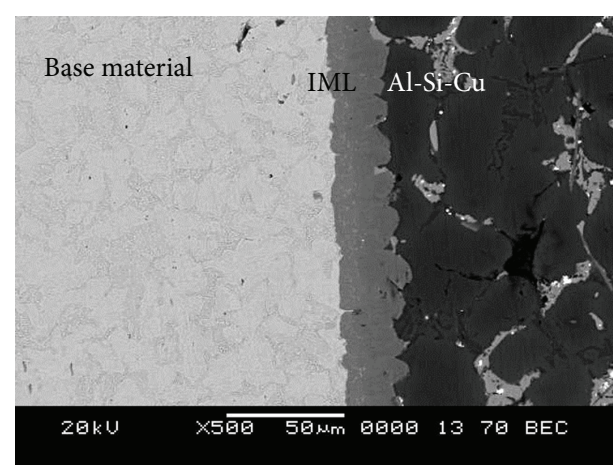

(a)

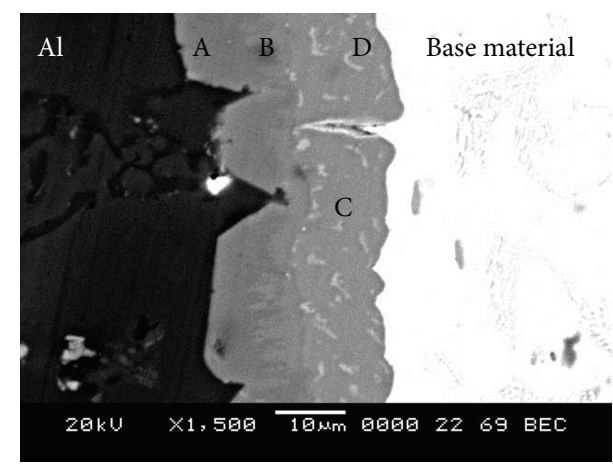

(b)

FIGURE 1: Cross-sectional BSE micrographs of aluminized samples. (a) A low magnification micrograph showing morphology of the coating. (b) A magnified image from the interface showing morphology of various phases in the intermetallic layer. Chemical compositions at locations $\mathrm{A}, \mathrm{B}, \mathrm{C}$, and $\mathrm{D}$ are given in Table 1.

the growth of intermetallic layer $[4,13]$. Addition of $\mathrm{Cu}$ has an additional effect that promotes formation of cubic variant for $\mathrm{Al}_{7} \mathrm{Fe}_{2} \mathrm{Si}$ [9]. Cubic variants are better than hexagonal variants because of improved ductility [14]. Also, Al-Si-Cu alloy is one of the filler metals used during dissimilar TIG welding of aluminum alloys to stainless steels $[15,16]$. To the best of our knowledge there is no reported investigations on the combined effect of $\mathrm{Si}$ and $\mathrm{Cu}$ on the intermetallic layer formation during hot-dip aluminizing. In the present work an attempt has been made to study the kinetics of various intermetallic phases formed as a function of time during hotdip aluminizing of steel with $\mathrm{Al}-7 \% \mathrm{Si}-2 \% \mathrm{Cu}$ bath at a dipping temperature of $690^{\circ} \mathrm{C}$.

\section{Materials and Methods}

The substrate used in this experiment is a low carbon steel having the following composition (all are in wt\%): C- $0.24 \%$, $\mathrm{Si}-0.29 \%$, and $\mathrm{Mn}-0.54 \%$. The substrate was in the form of a cold rolled strip. Coupons of dimensions $3 \mathrm{~mm} \times 8 \mathrm{~mm}$ $\times 50 \mathrm{~mm}$ were cut, metallographically polished, and used for aluminizing. Before aluminizing samples were precleaned using $10 \%$ hydrochloric acid, followed by washing with distilled water and drying.

Samples were dipped in a melt of Aluminum-7Si-2Cu (all are in wt\%). The aluminizing was conducted at $690^{\circ} \mathrm{C}$ temperature $\left( \pm 5^{\circ} \mathrm{C}\right)$ for different dipping times $(300 \mathrm{~s}, 600 \mathrm{~s}$, $900 \mathrm{~s}, 1500 \mathrm{~s}$, and $2400 \mathrm{~s}$ ). After dipping for predetermined time, the sample was removed and cooled rapidly in air. During melting and aluminizing, the $\mathrm{Al}$ melt was covered with a flux made using an eutectic mixture of zinc chloride and ammonium chloride (ratio being $3: 1$ by weight). The specimens were cut across the cross-section, metallographically polished, and etched using 3\% nital solution. Microstructures were studied using scanning electron microscope (SEM) and the chemical composition was measured using EDS (Energy Dispersive Spectroscopy). The intermetallic layer thickness was measured over a large number of locations $(>40)$ spread on 4 surfaces.

\section{Results}

Figure 1(a) shows a typical cross-sectional micrograph of the interface between the base material and Al-Si topcoat. Besides topcoat and base material, it has a continuous intermetallic layer (IML). The thickness of the intermetallic layer was varying across the length of the interface. Figure 1(b) shows a magnified image from Figure 1(a). It indicates that the IML consists of a number of intermetallic phases. Chemical compositions at various locations (A to D) in the IML was estimated, and they are given in Table 1. Using morphological information shown in Figure 1(b) and chemical composition shown in Table 1, we identify four intermetallic phases in the IML. They are at A: $\tau_{5}-\mathrm{Al}_{7} \mathrm{Fe}_{2} \mathrm{Si}$, at $\mathrm{B}: \theta-\mathrm{FeAl}_{3}$, at $\mathrm{C}: \eta-\mathrm{Fe}_{2} \mathrm{Al}_{5}$, and at $\mathrm{D}: \tau_{1}-\mathrm{Al}_{2} \mathrm{Fe}_{3} \mathrm{Si}_{3}$.

Figures 2(a) and 2(b) show IML formation at $690^{\circ} \mathrm{C}$ for dipping times of $300 \mathrm{~s}$ and $2400 \mathrm{~s}$, respectively. At the initial dipping time of $300 \mathrm{~s}$ the thickness of total IML is in the range of $8-24.6 \mu \mathrm{m}$ with an average value of $17.5 \mu \mathrm{m}$. Within the IML, $\left(\tau_{5}+\theta\right)$ layer formed the largest fraction. Since the thickness of $\theta-\mathrm{FeAl}_{3}$ layer is very small, the thickness of $\theta$ $\mathrm{FeAl}_{3}$ and $\tau_{5}-\mathrm{Al}_{7} \mathrm{Fe}_{2} \mathrm{Si}$ was measured together. With increase in dipping time, the thickness of $\eta-\mathrm{Fe}_{2} \mathrm{Al}_{5}$ layer increased rapidly, while increase in $\left(\tau_{5}+\theta\right)$ layer was relatively gradual. At dipping time of $2400 \mathrm{~s}$ the average thickness of $\eta-\mathrm{Fe}_{2} \mathrm{Al}_{5}$ was more than that of $\left(\tau_{5}+\theta\right)$ layer.

\section{Discussion}

4.1. Microstructural Features. From Figures 1(a), 1(b), 2(a), and 2(b) we see that the intermetallic layer consists of four phases, namely, $\tau_{5}-\mathrm{Al}_{7} \mathrm{Fe}_{2} \mathrm{Si}$ (with $\mathrm{Cu}$ ), $\theta-\mathrm{FeAl}_{3}, \eta-\mathrm{Fe}_{2} \mathrm{Al}_{5}$, and $\tau_{1}-\mathrm{Al}_{2} \mathrm{Fe}_{3} \mathrm{Si}_{3}$. This is true for all time scales investigated. As expected near Al-Si topcoat we have $\tau_{5}$ which is richer in Al compared to $\eta$ (which is near steel side). Presence of $\tau_{5^{-}}$ $\mathrm{Al}_{7} \mathrm{Fe}_{2} \mathrm{Si}, \theta-\mathrm{FeAl}_{3}, \eta-\mathrm{Fe}_{2} \mathrm{Al}_{5}$, and $\tau_{1}-\mathrm{Al}_{2} \mathrm{Fe}_{3} \mathrm{Si}_{3}$ is reported for the case of Al-5Si and Al-10Si bath [9]. Other phases in the $\mathrm{Fe}-\mathrm{Al}$ system like $\mathrm{Fe}_{3} \mathrm{Al}$, FeAl which were observed by $\mathrm{Li}$ et al. [11] in the case of Fe-Al system were not observed. 


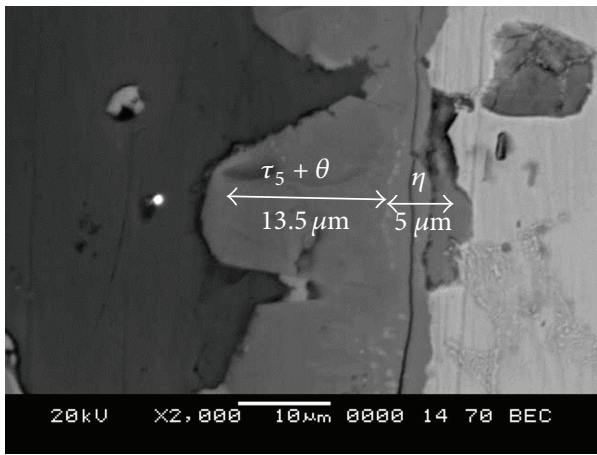

(a)

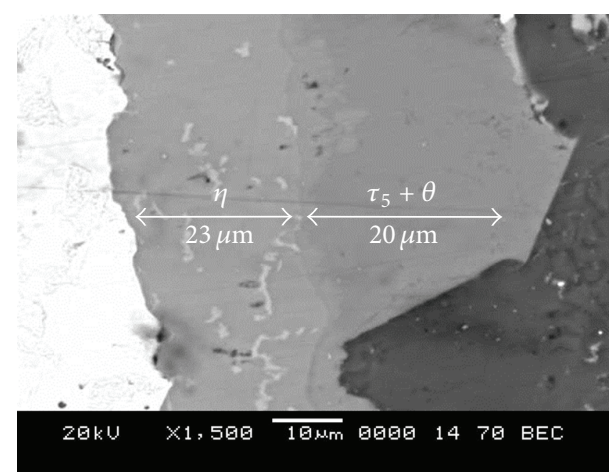

(b)

FIGURE 2: Intermetallic layer formed between substrate and Al-Si topcoat for dipping times of (a) $300 \mathrm{~s}$ and (b) $2400 \mathrm{~s}$ at $690^{\circ} \mathrm{C}$ temperature.

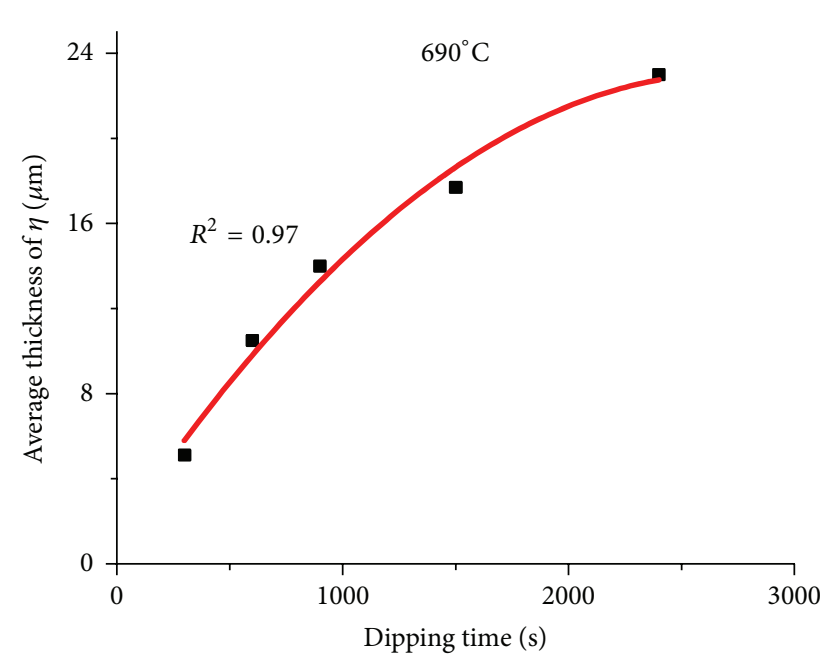

(a)

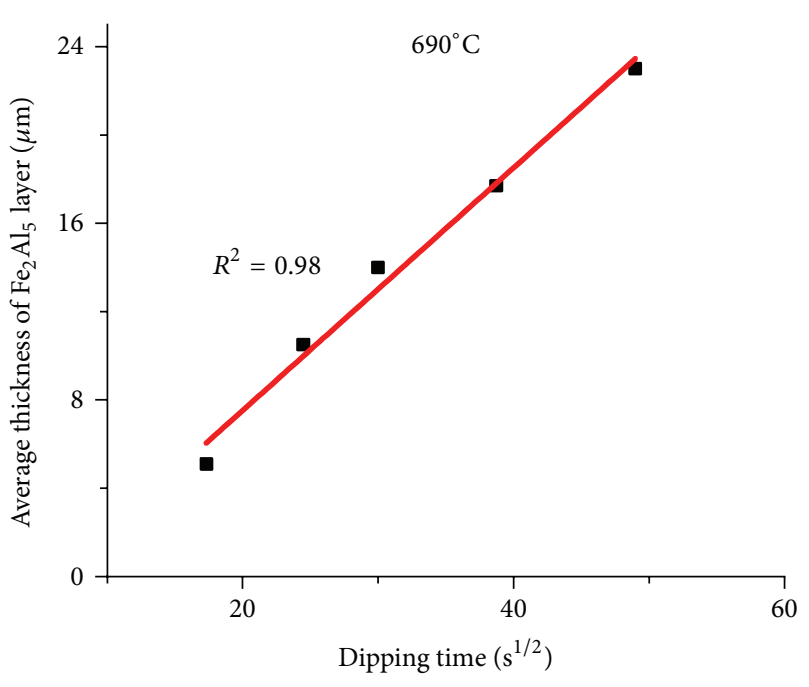

(b)

FIGURE 3: Plots of intermetallic layer growth. (a) Variation of average thickness of $\eta$ layer with dipping time. (b) Plot of $\eta$ thickness with square root of dipping time.

TABLE 1: Chemical compositions (at\%) at various points identified in Figure 1(b).

\begin{tabular}{lcccc}
\hline Location & $\mathrm{Al}$ & $\mathrm{Fe}$ & $\mathrm{Si}$ & $\mathrm{Cu}$ \\
\hline $\mathrm{A}$ & 73.81 & 16.89 & 7.72 & 1.58 \\
$\mathrm{~B}$ & 74.22 & 22.09 & 3.68 & - \\
$\mathrm{C}$ & 69.35 & 27.23 & 3.42 & - \\
$\mathrm{D}$ & 43.58 & 25.51 & 30.75 & - \\
\hline
\end{tabular}

$\tau_{5}$ is the only layer which had $\mathrm{Cu}$ in it, which could be detected by SEM-EDS. All other phases were devoid of $\mathrm{Cu}$. Song et al. [15] and Lin et al. [16] have reported partial substitution of $\mathrm{Al}$ by $\mathrm{Cu}$ in $\theta-\mathrm{FeAl}_{3}$.

Although the phase $\tau_{1}-\mathrm{Al}_{2} \mathrm{Fe}_{3} \mathrm{Si}_{3}$ is discontinuous and embedded in $\eta-\mathrm{Fe}_{2} \mathrm{Al}_{5}$, we can say that the diffusion path from iron side is $\mathrm{BCC} \mathrm{Fe}-\mathrm{Fe}_{2} \mathrm{Al}_{5}, \tau_{1}, \theta$, and $\tau_{5}$. It is to be noted that when $\mathrm{Si}$ content in $\mathrm{Fe}_{2} \mathrm{Al}_{5}$ layer increases more than 4.7 at $\%, \tau_{1}$ is getting precipitated in $\mathrm{Fe}_{2} \mathrm{Al}_{5}$ layer [9]. $\tau_{5}$ is present very close to $\mathrm{Al}-\mathrm{Si}-\mathrm{Cu}$ topcoat. Its thickness is continuously varying. In the literature [9] Cheng and Wang have reported two variants for $\tau_{5}$, that is, $\tau_{5(\mathrm{c})}(\mathrm{cubic})$ and $\tau_{5(\mathrm{H})}$ (hexagonal). Hexagonal variant has a chemical formula corresponding to $\mathrm{Al}_{7} \mathrm{Fe}_{2} \mathrm{Si}$, and cubic variant has a chemical formula corresponding to $\mathrm{Al}_{7}(\mathrm{Fe}, M)_{2} \mathrm{Si}$, where $M$ can be copper, cobalt, or manganese. From mechanical property point of view cubic variant is desirable than hexagonal variant [14].

4.2. Growth of Intermetallic Layers. Figures 1 and 2 indicate that the intermetallic layer is not smooth. This is also true for individual layers, namely, $\eta-\mathrm{Fe}_{2} \mathrm{Al}_{5}$ and $\left(\tau_{5}+\theta\right)$ layers. Hence thickness is measured over a relatively larger area, covering four sides of the sample. The reported thickness values are average of at least 40 readings. Figure 3(a) shows variation of $\eta-\mathrm{Fe}_{2} \mathrm{Al}_{5}$ layer thickness as a function of dipping time. As dipping time increases, the $\eta-\mathrm{Fe}_{2} \mathrm{Al}_{5}$ layer thickness 
increases and the relation is a parabolic one with a fitting coefficient $R^{2}=0.97$. A plot of thickness of $\eta-\mathrm{Fe}_{2} \mathrm{Al}_{5}$ layer against square root of the dipping time is drawn (Figure 3(b)), and the rate constant estimated is $0.57 \mu \mathrm{m} / \mathrm{s}^{1 / 2}$. We can write kinetics of growth of $\eta-\mathrm{Fe}_{2} \mathrm{Al}_{5}$ as $X_{\left(\mathrm{Fe}_{2} \mathrm{Al}_{5}\right)}=(2 k t)^{1 / 2}$, where $X$ is thickness, $k$ is rate constant, and $t$ is dipping time. The value of rate constant is much less than in the case of a bath without silicon and copper [5]. It is assumed that at this temperature, the dissolution of the substrate in the molten bath is negligible.

With increase in dipping time the growth rate of $\eta-\mathrm{Fe}_{2} \mathrm{Al}_{5}$ layer is higher as compared to that of $\left(\tau_{5}+\theta\right)$ layer. Therefore, at higher dipping times the tongue-like morphology or the waviness of the $\eta-\mathrm{Fe}_{2} \mathrm{Al}_{5}$ layer is more pronounced. The literature [5] reports that this tongue-like morphology is a result of favourable path for aluminum atoms to diffuse along $c$-axis of the $\mathrm{Fe}_{2} \mathrm{Al}_{5}$ orthorhombic structure.

Figure 4 shows variation of $\left(\tau_{5}+\theta\right)$ layer with time, and an attempt to fit parabolic curve fitting shows very poor fitting. This may be due to various mechanisms involved in the formation of $\tau_{5}-\mathrm{Al}_{7} \mathrm{Fe}_{2} \mathrm{Si}$. Literature [9] reports that (i) $\tau_{5}$ can be formed by the interdiffusion of $\mathrm{Al}$ and $\mathrm{Si}$ towards steel and steel towards molten Al bath, (ii) $\tau_{5}$ can be formed as a product of eutectic reaction during cooling from diffusion temperature. The report also says that $\tau_{5}$ phase is a metastable phase which is forming only during fast solidification after aluminizing using high silicon baths. Also, it is reported that the $\theta-\mathrm{FeAl}_{3}$ layer follows quasilinear growth behavior with time [5].

4.3. Comparative Growth of $\eta-\mathrm{Fe}_{2} \mathrm{Al}_{5}$ with respect to $\left(\tau_{5}+\theta\right)$. Figure 5 shows a comparison of relative growth of $\eta-\mathrm{Fe}_{2} \mathrm{Al}_{5}$ with respect to $\left(\tau_{5}+\theta\right)$. We see that at lower dipping time $\left(\tau_{5}+\theta\right)$ layer is more compared to $\eta-\mathrm{Fe}_{2} \mathrm{Al}_{5}$ layer. In $\mathrm{Fe}-\mathrm{Al}$ system, Gibbs free energy for formation of $\theta$ is smaller than that of $\eta$. When $\mathrm{Fe}$ is dipped in molten $\mathrm{Al}, \mathrm{FeAl}_{3}$ layer forms first by interfacial reaction. Later $\mathrm{Al}$ diffuses through $\mathrm{FeAl}_{3}$ layer to form $\mathrm{Fe}_{2} \mathrm{Al}_{5}$ layer. Dybkov [17] have reported that, for the formation of a second compound layer, a minimum thickness of first compound layer is essential. Bouché et al. [5] have reported that growth kinetics of $\eta-\mathrm{Fe}_{2} \mathrm{Al}_{5}$ is always greater than that of $\theta-\mathrm{FeAl}_{3}$, at $800^{\circ} \mathrm{C}$. So at higher dipping time more of $\eta-\mathrm{Fe}_{2} \mathrm{Al}_{5}$ compared to $\theta-\mathrm{FeAl}_{3}$.

4.4. Overall Growth Behavior of Intermetallics. Figure 6 shows variation of total intermetallic layer (IML) thickness as a function of time. The IML thickness value is very low compared to IML formation in the case of steel-Al 8 combination $[5,10,11,18,19]$. The values are still low compared to IML values reported by Hwang et al. [20] who has done aluminizing at $660^{\circ} \mathrm{C}$ using a bath of $\mathrm{Al}-9 \mathrm{wt} \%$ $\mathrm{Si}$. It is reported [13] that the elements like $\mathrm{Cu}$ and $\mathrm{Si}$ can decrease the activity coefficient of $\mathrm{Al}$ in $\mathrm{Fe}$ so as to reduce the thickness of intermetallic layer forming at the interface. The $\mathrm{Si}$ in the $\mathrm{Fe}_{2} \mathrm{Al}_{5}$ occupies vacancies in the $c$-axis of the crystal structure and reduces diffusion of $\mathrm{Al}$ towards $\mathrm{Fe}$ side. Comparing the experimental data with the reported data we can conclude that $\mathrm{Cu}$ and $\mathrm{Si}$ can be added in a view to control

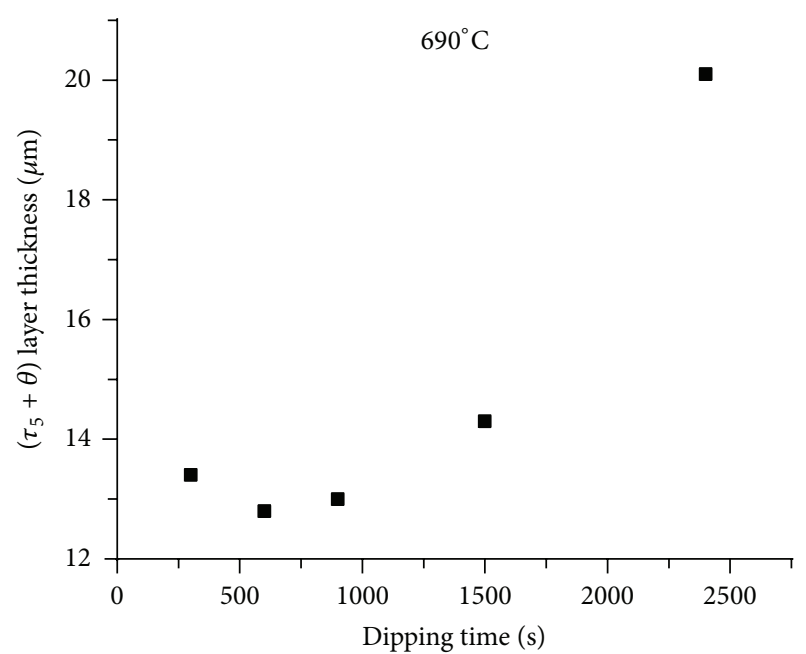

FIGURE 4: Variation of average thickness of $\tau_{5}+\theta$ layer with square root of dipping time.

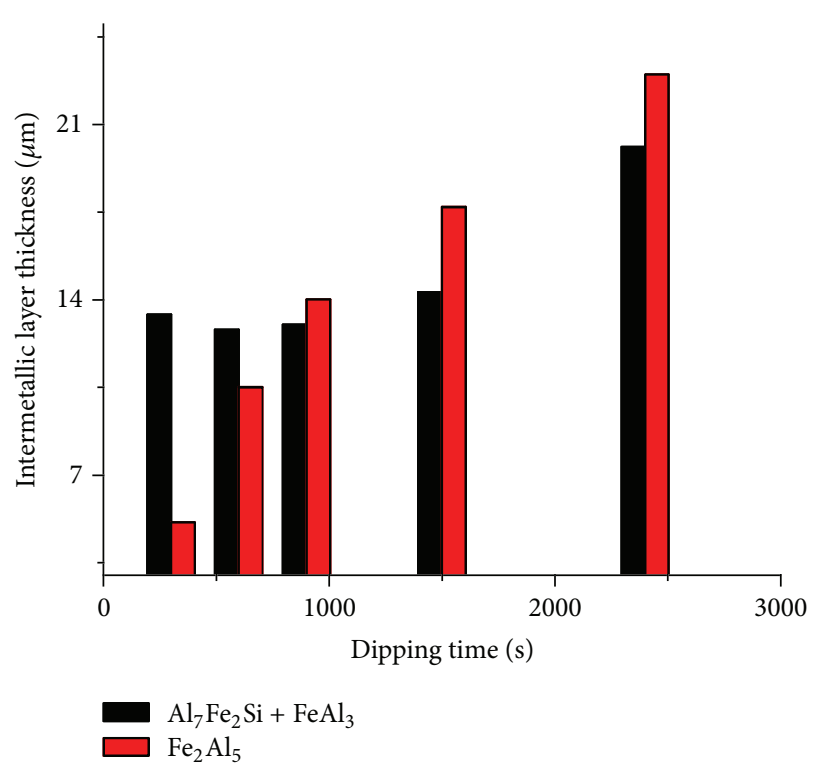

FIGURE 5: Relative growth of $\eta-\mathrm{Fe}_{2} \mathrm{Al}_{5}$ and $\theta+\tau_{5}\left(\mathrm{Al}_{7} \mathrm{Fe}_{2} \mathrm{Si}+\mathrm{FeAl}_{3}\right)$ layers as a function of dipping time.

the thickness of the intermetallic layer. The critical limit for intermetallic layers in $\mathrm{Al}-\mathrm{Fe}$ dissimilar joints with respect to their mechanical properties is about $10 \mu \mathrm{m}[8,21]$.

\section{Conclusions}

Low carbon steel is hot-dip aluminized using $\mathrm{Al}-7 \mathrm{Si}-2 \mathrm{Cu}$ bath at $690^{\circ} \mathrm{C}$ for time in the range of $300 \mathrm{~s}$ to $2400 \mathrm{~s}$. The intermetallic layer consisted of four phases, namely, $\tau_{5}{ }^{-}$ $\mathrm{Al}_{7} \mathrm{Fe}_{2} \mathrm{Si}$ (with $\mathrm{Cu}$ ), $\theta-\mathrm{FeAl}_{3}, \eta-\mathrm{Fe}_{2} \mathrm{Al}_{5}$, and $\tau_{1}-\mathrm{Al}_{2} \mathrm{Fe}_{3} \mathrm{Si}_{3}$. The growth of $\mathrm{Fe}_{2} \mathrm{Al}_{5}$ layer is diffusion controlled with a parabolic rate constant of $0.57 \mu \mathrm{m} / \mathrm{s}^{1 / 2}$. The value is much less than 


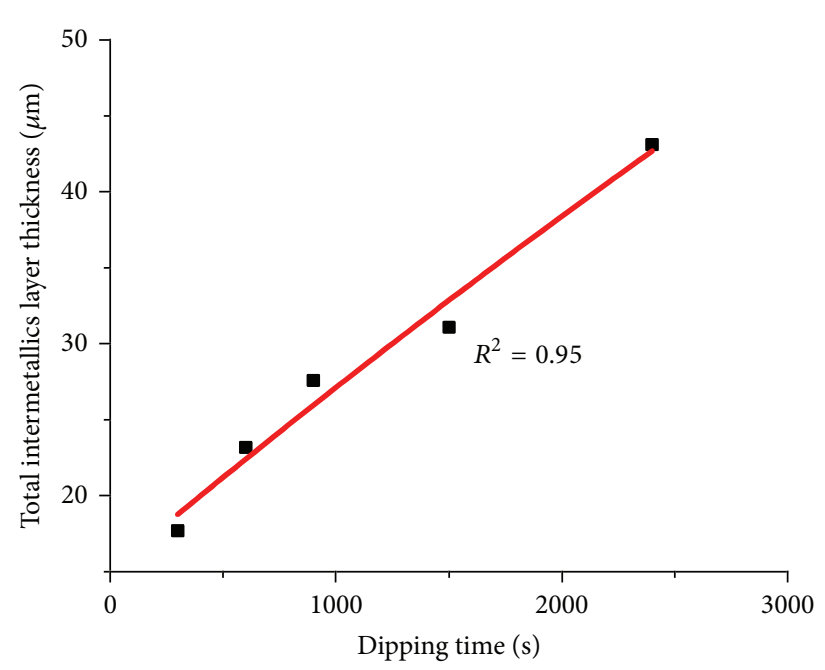

(a)

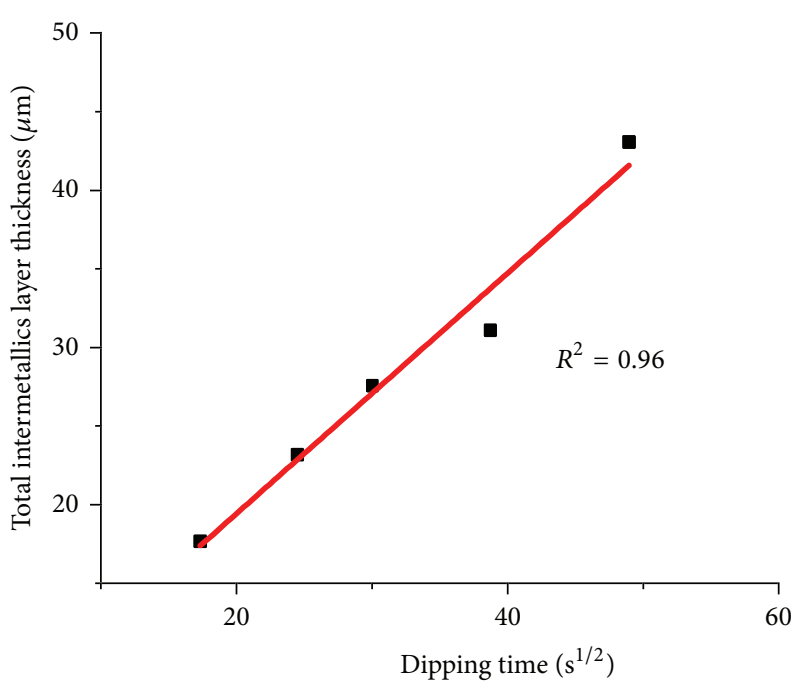

(b)

FIGURE 6: Polynomial fit of intermetallic growth. (a) Shows polynomial fit of total intermetallics layer as a function of dipping time; (b) shows a linear fit of total intermetallics layer thickness as a function of square root of dipping time.

that reported in the literature for Al-Si bath. The overall intermetallic growth is also parabolic in nature.

\section{References}

[1] Y.-Y. Chang, C.-C. Tsaur, and J. C. Rock, "Microstructure studies of an aluminide coating on 9Cr-1Mo steel during high temperature oxidation," Surface and Coatings Technology, vol. 200, no. 22-23, pp. 6588-6593, 2006.

[2] C.-J. Wang and S.-M. Chen, "The high-temperature oxidation behavior of hot-dipping Al-Si coating on low carbon steel," Surface and Coatings Technology, vol. 200, no. 22-23, pp. 6601$6605,2006$.

[3] J. Maki, M. Suehiro, and Y. Ikematsu, "Alloying reaction of aluminized steel sheet," ISIJ International, vol. 50, no. 8, pp. 1205-1210, 2010.

[4] E. Gebhardt and W. Obrowski, "Reactionen von festem eisenmit schmelzen aus aluminium und aluminumlegierungen," Metallkunde, vol. 4, p. 154, 1953.

[5] K. Bouché, F. Barbier, and A. Coulet, "Intermetallic compound layer growth between solid iron and molten aluminium," Materials Science and Engineering A, vol. 249, no. 1-2, pp. 167$175,1998$.

[6] A. Bouayad, C. Gerometta, A. Belkebir, and A. Ambari, "Kinetic interactions between solid iron and molten aluminium," Materials Science and Engineering A, vol. 363, no. 1-2, pp. 53-61, 2003.

[7] V. I. Dybkov, "Interaction of $18 \mathrm{Cr}-10 \mathrm{Ni}$ stainless steel with liquid aluminium," Journal of Materials Science, vol. 25, no. 8, pp. 36153633, 1990.

[8] H. Springer, A. Kostka, E. J. Payton, D. Raabe, A. KaysserPyzalla, and G. Eggeler, "On the formation and growth of intermetallic phases during interdiffusion between low-carbon steel and aluminum alloys," Acta Materialia, vol. 59, no. 4, pp. 1586-1600, 2011.

[9] W.-J. Cheng and C.-J. Wang, "Effect of silicon on the formation of intermetallic phases in aluminide coating on mild steel," Intermetallics, vol. 19, no. 10, pp. 1455-1460, 2011.
[10] W.-J. Cheng and C.-J. Wang, "Characterization of intermetallic layer formation in aluminide/nickel duplex coating on mild steel," Materials Characterization, vol. 69, pp. 63-70, 2012.

[11] Y.-J. Li, J. Wang, and X. Holly, "X-ray diffraction and TEM analysis of $\mathrm{Fe}-\mathrm{Al}$ alloy layer in coating of new hot dip aluminised steel," Materials Science and Technology, vol. 19, no. 5, pp. 657-660, 2003.

[12] K. U. Bhat, P. Huilgol, and J. Jithin, "Aluminising of mild steel plates," ISRN Metallurgy, vol. 2013, Article ID 191723, 6 pages, 2013.

[13] M. V. Akdeniz and A. O. Mekhrabov, "The effect of substitutional impurities on the evolution of Fe-Al diffusion layer," Acta Materialia, vol. 46, no. 4, pp. 1185-1192, 1998.

[14] W.-Y. Kim, D. E. Luzzi, and D. P. Pope, "Room temperature deformation behavior of the Hf-V-Ta C15 Laves phase," Intermetallics, vol. 11, no. 3, pp. 257-267, 2003.

[15] J. L. Song, S. B. Lin, C. L. Yang, C. L. Fan, and G. C. Ma, "Analysis of intermetallic layer in dissimilar TIG weldingbrazing butt joint of aluminium alloy to stainless steel," Science and Technology of Welding and Joining, vol. 15, no. 3, pp. 213-218, 2010.

[16] S. B. Lin, J. L. Song, C. L. Yang, C. L. Fan, and D. W. Zhang, "Brazability of dissimilar metals tungsten inert gas butt welding-brazing between aluminum alloy and stainless steel with Al-Cu filler metal," Materials and Design, vol. 31, no. 5, pp. 2637-2642, 2010.

[17] V. I. Dybkov, "Phase stability during growth of compound layers," Materials Science Forum, vol. 155-156, pp. 31-38, 1994.

[18] W. Zhang, D. Sun, L. Han, W. Gao, and X. Qiu, "Characterization of intermetallic compounds in dissimilar material resistance spot welded joint of high strength steel and aluminum alloy," ISIJ International, vol. 51, no. 11, pp. 1870-1877, 2011.

[19] W. Deqing, S. Ziyuan, and Z. Longjiang, "A liquid aluminum corrosion resistance surface on steel substrate," Applied Surface Science, vol. 214, no. 1-4, pp. 304-311, 2003. 
[20] S.-H. Hwang, J.-H. Song, and Y.-S. Kim, "Effects of carbon content on its dissolution in to molten aluminum alloy," Materials Science and Engineering, vol. 390, pp. 437-443, 2005.

[21] D. R. G. Achar, J. Ruge, and S. Sundaresan, "Metallurgical and mechanical investigations of aluminum-steel fusion welds," Aluminium, vol. 56, no. 6, pp. 391-397, 1980. 

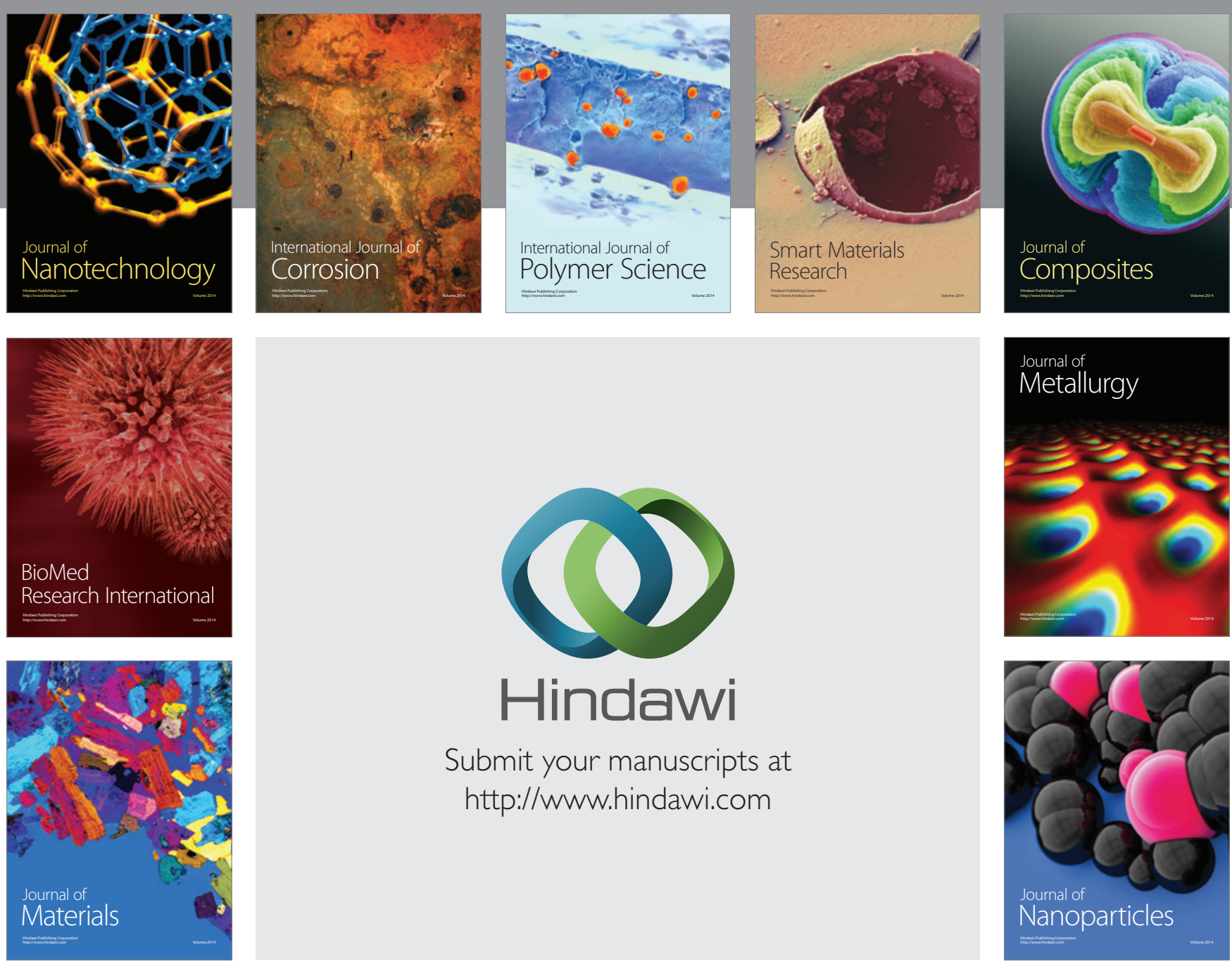

Submit your manuscripts at http://www.hindawi.com
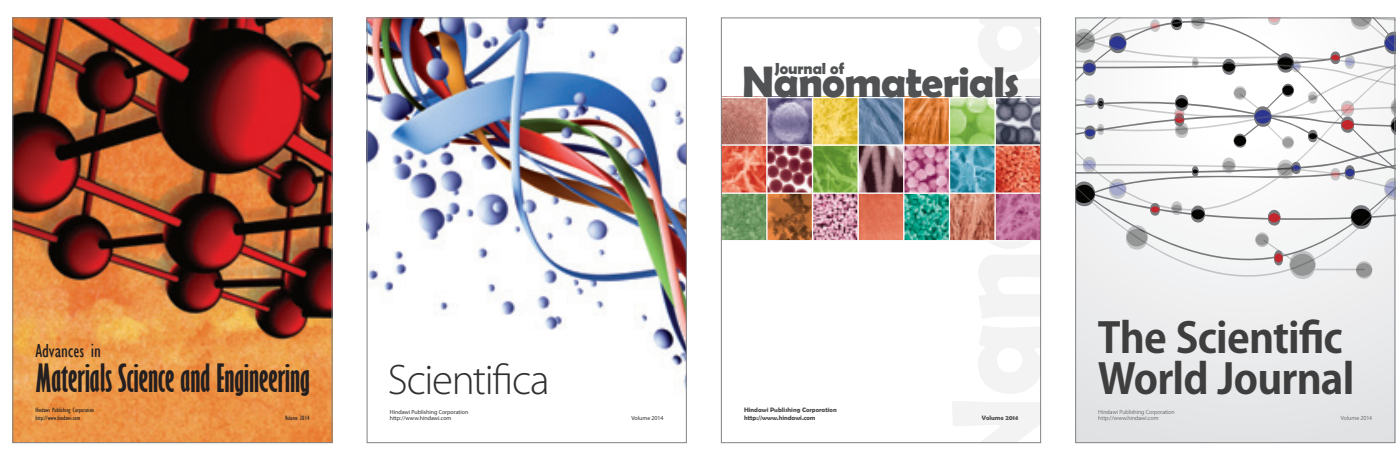

\section{The Scientific World Journal}
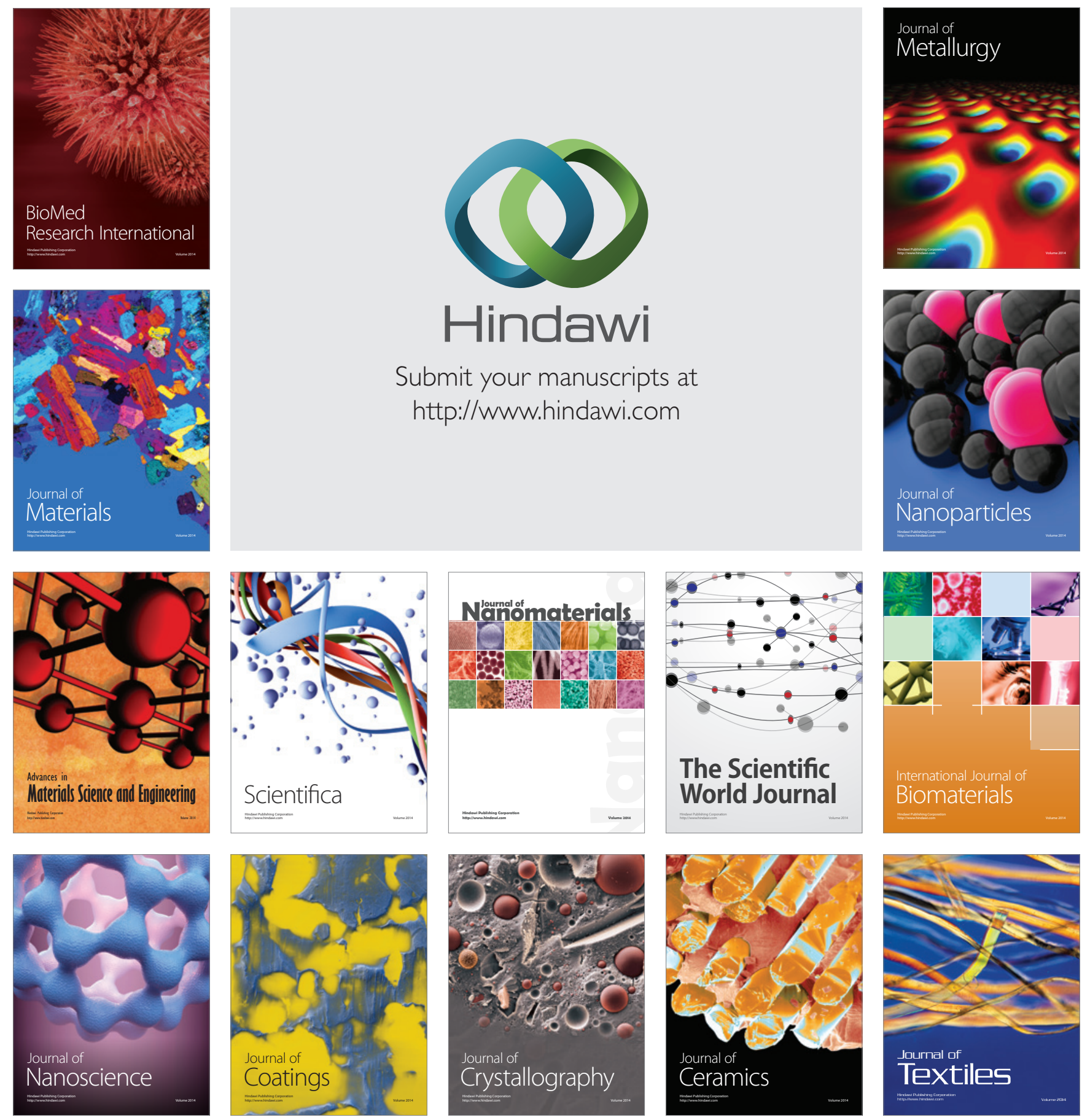